Research Article

\title{
INTEGRATED MANAGEMENT PRACTICES FOR CLUBROOT DISEASE (PLASMODIOPHORA BRASSICAE WOR.) OF CAULIFLOWER IN PALUNG, MAKWANPUR, NEPAL
}

\author{
P. Adhikari", A. Khatiwada, N. Paneru and P. Tandan \\ Faculty of Agriculture, Agriculture and Forestry University, Rampur, Chitwan, Nepal
}

\begin{abstract}
Club root is one of the most important diseases in the eastern hills of Nepal affecting the rural income as well as quantity and quality of Cauliflower production. A field experiment was conducted in Randomized Complete Block Design (RCBD) with 5 treatments and 4 replications during February to May, 2019. The experiment was conducted in the Farmer's field in the disease prone area of Thaha municipality-4, Palung of Makwanpur district to assess the efficacy of five different treatments; Nebijin, Hatake, Trichoderma viride, Lime and control for the management or suppressing the club root disease. The effectiveness of the treatments against club root disease was evaluated along with their influence on growth parameters and yield parameters of white top variety of cauliflower. Different parameters such as disease incidence, percent disease index (PDI) or disease severity index (DSI) and percent disease control (PDI) were recorded using disease scoring scale. The treatments showed significant effect on the yield and disease parameters, but not on the vegetative parameters of cauliflower. The lowest disease incidence $(50.2 \%)$ and severity index $(26.8 \%)$ and the highest percent disease control (57.6\%) was recorded in Nebijin. Moreover, the Marketable yield $\left(\mathrm{Mtha}^{-1}\right)$ per plot was observed highest from Nebijin (48.27Mtha $\left.{ }^{-1}\right)$ and Trichoderma viride (47.39 $\mathrm{Mtha}^{-1}$ ) treatment. From the study it may concluded that the application of Nebijin was more effective for the management of clubroot disease of Cauliflower and the use of Hatake and Trichoderma virideas bio-fungicides were also giving the potential assuring measure for the controlling disease of Cauliflower.
\end{abstract}

Keywords: Cauliflower, Clubroot, Hatake, Trichoderma viride, Nebijin

\section{INTRODUCTION}

Cauliflower (Brassica oleracea var. botrytis L.) is an important winter vegetable crop successfully grown in Terai to high hills in normal to off-season in Nepal (APP,

*Corresponding author: pragya.adhikari20@gmail.com

Received: 03.10.2019

Accepted: 10.02 .2020 
1955). It is consumed as cooked vegetables and as pickle. It is nutritionally rich and has medicinal value(Joshi et al., 2018) and also excellent source of minerals such as calcium, iron, magnesium, potassium, sodium, and phosphorous. Among the different cruciferous vegetables grown in Nepal, cauliflower, cabbage and radish considered major one. In the year 2015/16, this group shares 32\% of total area (79954.1 ha) and $35.1 \%$ of total production $(3700969 \mathrm{Mt})$ of vegetables in the country whereby cauliflower has the highest share of $14.0 \%$ in area under cultivation (34967 ha) and $14.9 \%$ in total vegetables production of the country $(550044.8 \mathrm{Mt})$, which is the highest among all the vegetables (MOAD, 2016).

Club root of cruciferous plants caused by Plasmodiophora brassicae is an economically important soil borne disease. The disease has been reported in more than 60 countries and can result in total yield loss in heavily infested field (Dixon, 2009). The disease affects a wide host range and is very problematic in Brassica vegetable production (Burnett, 2013). In Nepal, For the first-time club root disease samples of broccoli, knolkhol, from one of the farmers of Kathmandu was received at Plant Pathology Division in 1993 (PPD, 2000). Then outbreak of this disease was reported from Bhaktapur following Palung valley of Makwanpur district through the movement of seedlings. This pathogen persists in soil as apparently very durable resting spores and is reputedly capable of remaining viable and dormant for at least 20 years. The severity of infestation and symptom expression increases with the intensity of crop production (Dixon, 2009). It is very difficult to eradicate once established in the field. High levels of club root (>90\% CI) occur at temperature of $\sim 24^{\circ} \mathrm{C}$, constant and fluctuating moisture of $70 \%$ and in Acidic soil condition (Colhoun, 1953). Club root disease has been an important constraint to production of Brassica vegetables as it causes of the economic losses, but more importantly because of the difficulties with the management of the pathogen. The control of disease is very difficult using the conventional methods and practices. In this context, Integrated management measures could be effective for the control of club root problem. An integrated Management practice includes holistic measures such as cultural, biological, chemical control measures for the control of disease. This research was conducted to evaluate the effectiveness of integrated management practices for the club root disease of cauliflower in field condition.

\section{MATERIALS AND METHODS}

The experiment was conducted in a disease prone area at Palung, Makwanpur during February to May, 2019. The site locates at 27.63301 Latitude and 85.06701 Longitude with the altitude of 1788 masl. White top variety of cauliflower was chosen for the experiment. The experiment setup was carried out in single factorial Randomized Complete Block Design with 5 treatments and 4 replications: Nebijin, Hatake, Trichoderma viride and lime. Seedlings were raised in a plug mix media under high tech plastic tunnel. Individual Plot size was dimensioned as $2.25 \times 1.8 \mathrm{~m}^{2}$ with 20 plants and $45 \mathrm{~cm} \times 45 \mathrm{~cm}^{2}$ spacing was maintained between row to row and 
plant to plant. The distance between replications was maintained $1 \mathrm{~m}$ and distance between plots was maintained $50 \mathrm{~cm}$. Soil sample was compositely prepared at the time of land preparation and send for routine analysis in Regional Agriculture Research station, Pokhara. Recommended doses of Chemical fertilizer @200:120:80 $\mathrm{kgha}^{-1}$ Urea, DAP, MOP and compost $20 \mathrm{mtha}^{-1}$ were applied. Side placement of half dose of nitrogen, full dose of phosphorous and full dose of potash were done as a basal after 1 week of transplanting and half dose of nitrogen was applied after 1 month of basal dose application. Irrigation was done in 1-2 days interval followed by 1 week interval. Weeding was conducted manually for 2 times during the cropping period. The occurrence of Mikania micrantha and chitlange grass was problematic weeds in research trial periphery.

Table 1. Treatments details

\begin{tabular}{|c|c|c|c|c|}
\hline Treatments & $\begin{array}{l}\text { Microbial species } \\
\text { or Chemical Name }\end{array}$ & $\begin{array}{l}\text { Trade } \\
\text { Name }\end{array}$ & Application Dose & Application Method \\
\hline $\mathrm{T}_{1}$ & Control & - & $\begin{array}{l}\text { Use of } \\
\text { recommended } \\
\text { doses of chemical } \\
\text { fertilizers only }\end{array}$ & As per farmers method \\
\hline $\mathrm{T}_{2}$ & Lime & Lime & $5440 \mathrm{~kg} \mathrm{ha}^{-1}$ & $\begin{array}{l}\text { Lime was applied } 2 \text { weeks } \\
\text { before transplanting as per } \\
\text { pH value of soil. }\end{array}$ \\
\hline $\mathrm{T}_{3}$ & Trichoderma viride & $\begin{array}{l}\text { Biocide } \\
\text { Trivi }\end{array}$ & $5 \mathrm{~L} \mathrm{t} \mathrm{ha}^{-1}$ & $\begin{array}{l}1^{\text {st }} \text { dose of Trichoderma } \\
\text { viride were applied } \\
\text { incorporated in soil before } \\
\text { transplanting }+2^{\text {nd }} \text { dose } \\
\text { was soil drenched at } \\
\text { 30DAT }\end{array}$ \\
\hline $\mathrm{T}_{4}$ & Flusulfamide & Nebijin & $30 \mathrm{~kg} \mathrm{ha}^{-1}$ & $\begin{array}{l}\text { Mixed with a soil in each } \\
\text { transplanting hole at the } \\
\text { time of application. }\end{array}$ \\
\hline $\mathrm{T}_{5}$ & $\begin{array}{l}\text { Bacillus } \\
\text { Amyloliquefaciens } \\
\text { D203 }\end{array}$ & Hatake & $1000 \mathrm{~g} \mathrm{ha}^{-1}$ & $\begin{array}{l}\text { Soil drenching } 3 \text { days } \\
\text { before transplanting and } \\
\text { then in every } 15 \text { days } \\
\text { interval. }\end{array}$ \\
\hline
\end{tabular}

Vegetative parameter such as plant height, canopy coverage and leaf number was recorded at 15, 30, 45 and 60 days after transplanting (DAT) respectively whereas, yield and disease parameters such as curd diameter, fresh root weight, marketable yield per plot, percentage disease incidence, percent disease index or disease severity, and percent disease control were recorded at the time of harvesting of cauliflower. 


\section{Disease scoring}

Severity of club root was assessed by visually estimating the degree of gall development on lateral and main root system using 0-3 disease scale given by (Kuginuki et al.,1999).

Disease scoring scale is presented in table 2

Table 2. Disease scoring scale used to score club root on cauliflower

\begin{tabular}{ccl}
\hline Sl. No. & Score & Severity \\
\hline 1 & 0 & no symptoms of galling \\
2 & 1 & A few small club (small galls on $<1 / 3$ of roots) \\
3 & 2 & moderate clubs (small to medium galls on $1 / 3-2 / 3$ of roots \\
4 & 3 & severe clubs (medium to large galls on $>2 / 3$ of roots) \\
\hline
\end{tabular}
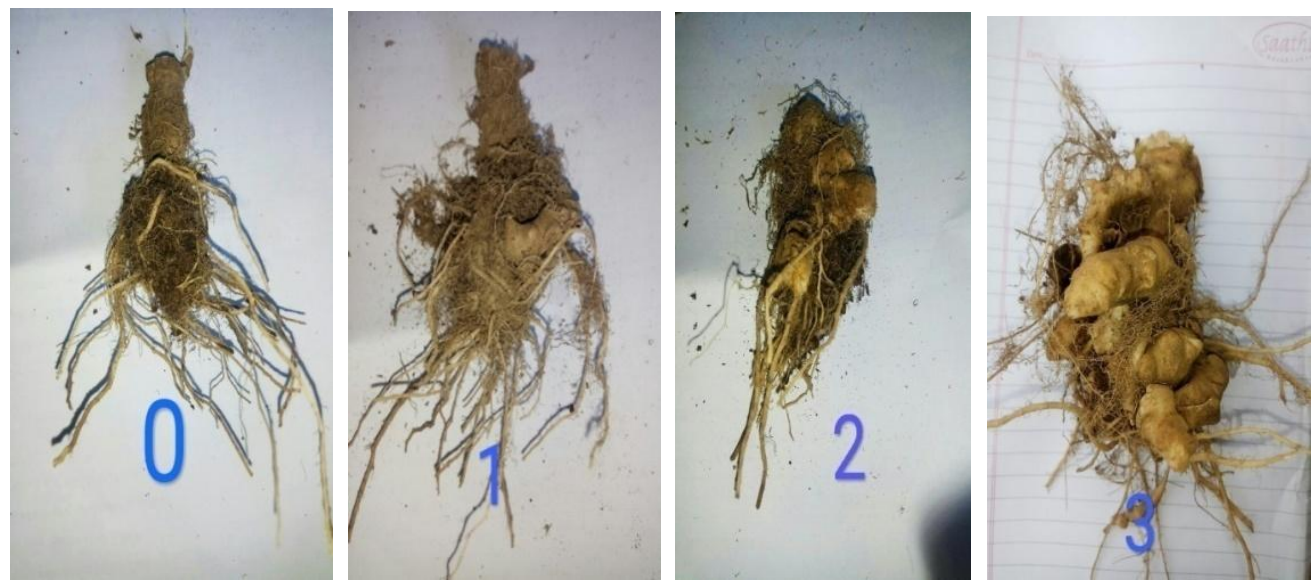

Figure 1. Disease scoring of infected root based on 0-3 scale

\section{Disease Assessment}

Six sampled plants per plot were uprooted and scored on a 0-3 scale (Kuginuki et al., 1999) by visual observation of gall formation of each plants roots. Club root severity of each plant was assessed. 


\section{Percent Disease Index (PDI) or Disease severity Index (DSI)}

Individual scores used to calculate an index of disease according to formula

$\operatorname{DSI}(\%)=\frac{\left.\sum \text { (Class no. }\right)(\text { No. of plants in each class })}{(\text { Total no. of plants per sample })(\text { No. classes }-1)}$

Disease Incidence (DI)

DI $(\%)=\frac{\text { Number of plants infested }}{\text { Total number of plants observed }}$

Percent Disease Control (PDC) or Disease control percentage

$\operatorname{PDC}(\%)=\frac{\text { PDI in control }- \text { PDI in treatment }}{\text { PDI in control }}$

\section{Statistical analysis}

All data were presented as mean \pm SEM. Statistical analysis was done by using MS EXCEL GENSTAT $15^{\text {th }}$ edition. Data were subjected to one-way analysis of variance (ANOVA) and means were compared by Duncan's Multiple Range Test (DMRT) to compare treatments means at $P=0.05$. Effectiveness of treatments was studied based on above mentioned parameter.

\section{RESULTS AND DISCUSSION}

\section{Chemical properties of experiment site soil:}

The soil of experiment site was found loamy in texture having $\mathrm{pH} 4.7$. The soil was low in organic matter content $(0.05 \%)$, poor in total nitrogen $(0.05 \%)$, high in available Phosphorus content $\left(1022.2 \mathrm{~kg} \mathrm{ha}^{-1}\right)$ and also high in available potash content $\left(516.0 \mathrm{~kg} \mathrm{ha}^{-1}\right)$.

Disease Incidence:

The disease incidence of clubroot disease on cauliflower was found to be significantly influenced by treatments application. The highest disease incidence [77.4(91.7\%)] was recorded in control which was statistically similar with lime [77.4(91.40\%)] application followed by Trichoderma viride treatment [66.9(75.0\%)] whereas, the least disease incidence was recorded in Hatake [47.4(54.20\%)] which was statistically identical with Nebijin treatment [50.2(58.3\%)]. Results are presented in Table 3. 
Table 3. Influence of treatments on the disease incidence of white top variety of cauliflower

\begin{tabular}{lc}
\hline \multicolumn{1}{c}{ Treatments } & Disease incidence (\%) \\
\hline Control & $77.4(91.7)^{\mathrm{a}}$ \\
Lime & $77.4(91.7)^{\mathrm{a}}$ \\
Trichoderma viride & $66.9(75.0)^{\mathrm{ab}}$ \\
Nebijin & $50.2(58.3)^{\mathrm{b}}$ \\
Hatake & $47.4(54.2)^{\mathrm{b}}$ \\
\hline SEM \pm & 7.60 \\
LSD & $23.42^{* *}$ \\
C.V $(\%)$ & 23.8 \\
Grand mean & 63.9 \\
\hline
\end{tabular}

Note: SEM \pm , Standard Error of mean; C.V, Coefficient of variation; LSD, Least significant difference. Means in the column with same letter (s) in superscript indicate no significant difference between treatments at 0.05 level of significance; '***' Significant at 0.001 level of Significance; ' $* *$ ' Significant at 0.01 level of Significance; '*' Significant at 0.05 level of Significance. Value in parenthesis indicates the original mean value.

Above findings shows that Hatake and Nebijin is highly effective against club root than other applied treatments. Several researches has corroborated the effectiveness of Nebijin against club root disease. Tanaka et al. (1999) investigated the mode of action of flusulfamide against $P$. brassicae in transplanted seedlings of Chinese cabbage. These authors highlighted that the flusulfamide acts directly on the resting spores and suppresses club root disease by inhibiting the germination of Plasmodiophora brassicae resting spores through adsorption into their cells wall. In an experiment conducted at Palung /Daman, Makwanpur to find effective management tactics in farmers infested field Timila, (2008) revealed that Nebijin is an effective treatment for reducing the club root disease incidence and severity by $40.4 \%$ and $59.5 \%$ which support the present research result of effectiveness of Nebijin. In Nepal for controlling club root, Trichoderma viride is found widely recommended but its effectiveness remains variable in the farmers' field. Cuevas et al. (2011) reported a reduction of Club root Disease incidence by $45 \%$ by the use of Trichoderma viride, as compared to fields with conventional crop practices. Likewise, Ghimire and Shrestha (2019) reported the effectiveness of Trichoderma viride in reducing the club root by $42.26 \%$ as compared to control. Moreover, soil liming has been used against club root for more than 200 years, but its effectiveness has proven to be extremely variable (Karling, 1968). Lime application does not eradicate the pathogen, but creates unfavorable conditions affecting processes such as invasion, colonization and symptom formation (Webster and Dixon, 1991). Tremblay et al. (2005) also supported the present result of lower effectiveness of lime over other combination of treatment practices by stating that single use of lime often falls 
short of a satisfactory control of club root disease. Timila (2006) reported that lime reduced incidence by $33 \%$. This low effectiveness of lime could be due to frequent rainfall in the trial area which caused leaching of lime active components.

\section{Disease severity and Disease control percentage}

The percent disease index or disease severity of club root disease on cauliflower was found to be significantly influenced by the application of treatments. It was calculated based on a (0-3) rating scale. Comparing all the treatments, control treatment showed the highest PDI [57.3(70.83\%)] statistically similar to PDI of Lime application [47.4(55.55\%)] followed by PDI of Trichoderma viride treatment [40.0(41.05\%]. The least PDI [33.7(31.92\%)] was recorded in the Nebijin followed by Hatake treatment. Least PDI of hatake treatment was supported by a research conducted on kavre showed that hatake reduced the disease severity by $75.8 \%$ compared to control i.e. $83.75 \%$ (Basnet et al., 2018). Hatake act as a metabolites that degrade cell walls of fungus and bacteria, to the disease cure and prevent plant diseases, and triggering the plant's immune system (Hatake, 2018).

In case of percent disease control or disease control percentage, the highest (70.7\%) was recorded in Nebijin treatment which was statistically similar with Hatake (54.4\%) and Trichoderma viride (41.0\%) treatment followed by lime application (29.4\%). The lowest PDC was recorded in control plots i.e. 0\%. Results are presented in table 4

Table 4. Influence of treatments on the disease severity and disease control percentage of white top variety of cauliflower

\begin{tabular}{lcc}
\hline \multicolumn{1}{c}{ Treatments } & $\begin{array}{c}\text { Percent disease Index or } \\
\text { Disease severity (PDI) }\end{array}$ & $\begin{array}{c}\text { Disease control percentage } \\
\text { or percent disease control (PDC) }\end{array}$ \\
\hline Control & $57.3(70.83)^{\mathrm{a}}$ & $0.0^{\mathrm{c}}$ \\
Lime & $47.4(55.55)^{\mathrm{ab}}$ & $29.4^{\mathrm{b}}$ \\
Trichoderma viride & $40.0(41.05)^{\mathrm{bc}}$ & $41.0^{\mathrm{ab}}$ \\
Nebijin & $26.8(20.83)^{\mathrm{d}}$ & $70.7^{\mathrm{a}}$ \\
Hatake & $33.7(31.92)^{\mathrm{cd}}$ & $54.4^{\mathrm{ab}}$ \\
\hline SEM $( \pm)$ & 4.01 & 36.1 \\
LSD & $12.34^{* * *}$ & $6.06^{* *}$ \\
C.V $(\%)$ & 19.5 & 29.68 \\
Grand mean & 41.0 & 33.6 \\
\hline
\end{tabular}

Note: SEM \pm , Standard Error of mean; CV, Coefficient of variation; LSD, Least significant difference. Means in the column with same letter (s) in superscript indicate no significant difference between treatments at 0.05 level of significance; '***' Significant at 0.001 level of Significance; '**' Significant at 0.01 level of Significance; '*' Significant at 0.05 level of Significance. Value in parenthesis indicates the original mean value. 


\section{Marketable yield}

The Marketable yield of cauliflower was found to be significantly influenced by different treatments applied. The highest marketable yield was recorded in Nebijin (48.27 Mt ha $\left.{ }^{-1}\right)$ which was statistically similar with Trichoderma viride treatment followed by Hatake (43.54 Mt ha ${ }^{-1}$ ) and Lime treatment (41.98 $\mathrm{Mt} \mathrm{ha}^{-1}$ ) and the least Marketable yield was recorded in control (35.53 $\left.\mathrm{Mt} \mathrm{ha}^{-1}\right)$. Results are presented in Table 5.

Table 5. Influence of treatments on the marketable yield $\left(\mathrm{Mt} \mathrm{ha}^{-1}\right)$ of white variety of cauliflower

\begin{tabular}{ll}
\hline Treatments & Marketable yield $\left(\mathrm{Mtha}^{-1}\right)$ \\
\hline Control & $35.53 \mathrm{c}$ \\
Lime & $41.98 \mathrm{~b}$ \\
Trichoderma viride & $47.39 \mathrm{a}$ \\
Nebijin & $48.27 \mathrm{a}$ \\
Hatake & $43.54 \mathrm{~b}$ \\
\hline SEM \pm & 0.912 \\
LSD & $2.811 * * *$ \\
C.V $(\%)$ & 4.2 \\
Grand mean & 43.34 \\
\hline
\end{tabular}

Note: SEM \pm , Standard Error of mean; CV, Coefficient of variation; LSD, Least significant difference. Means in the column with same letter (s) in superscript indicate no significant difference between treatments at 0.05 level of significance; '***' Significant at 0.001 level of Significance; '**' Significant at 0.01 level of Significance; '*' Significant at 0.05 level of Significance

In the present study, Good performance of Trichoderma viride in yield improvement supported by Basnet et al.(2018). This high effectiveness of Trichoderma maybe it's a free living fungus common in soil and root ecosystems, which is highly interactive in root, soil and foliar environments. It reduces growth, survival or infections caused by pathogens by different mechanisms like competition, antibiosis, myco parasitism, hyphal interactions, and enzyme secretion (Singh, 2010).

\section{Average Curd weight and Curd diameter}

The average curd weight $(\mathrm{kg})$ of cauliflower and curd diameter $(\mathrm{cm})$ both found to be significantly influenced by the treatments applied.

In case of weight $(\mathrm{kg})$ the highest curd weight $(0.977 \mathrm{~kg})$ was recorded in Nebijin treatment which was statistically similar with Trichoderma viride treatment $(0.9590$ $\mathrm{kg})$ followed by Hatake $(0.8813 \mathrm{~kg})$ and lime treatment $(0.8498 \mathrm{~kg})$ whereas the lowest curd weight $(0.7193 \mathrm{~kg})$ was recorded in control. Similarly, Nebijin treatment showed the highest cauliflower curd diameter $(16.54 \mathrm{~cm})$ which was statistically similar with Trichoderma viride treatment $(16.45 \mathrm{~cm})$ followed by Hatake $(15.71 \mathrm{~cm})$ and lime treatment $(14.96 \mathrm{~cm})$ and the least curd diameter $(13.56 \mathrm{~cm})$ was obtained in control treatment. Results are presented in Table 6. 
Table 6. Influence of treatments on the curd weight $(\mathrm{kg})$ and curd diameter $(\mathrm{cm})$ of white top variety of cauliflower

\begin{tabular}{lll}
\hline Treatments & Curd weight $(\mathrm{kg})$ & Curd diameter(cm) \\
\hline Control & $0.7193^{\mathrm{c}}$ & $13.56^{\mathrm{b}}$ \\
Lime & $0.8498^{\mathrm{b}}$ & $14.96^{\mathrm{ab}}$ \\
Trichoderma viride & $0.9590^{\mathrm{a}}$ & $16.45^{\mathrm{a}}$ \\
Nebijin & $0.9770^{\mathrm{a}}$ & $16.54^{\mathrm{a}}$ \\
Hatake & $0.8813^{\mathrm{b}}$ & $15.71^{\mathrm{ab}}$ \\
\hline SEM \pm & 0.01847 & 0.671 \\
LSD & $0.05690^{* * *}$ & $2.068^{*}$ \\
C.V(\%) & 4.2 & 8.7 \\
Grand mean & 0.8773 & 15.44 \\
\hline
\end{tabular}

Note: SEm \pm , Standard Error of mean; CV, Coefficient of variation; LSD, Least significant difference. Means in the column with same letter (s) in superscript indicate no significant difference between treatments at 0.05 level of significance; '***' Significant at 0.001 level of Significance; '**' Significant at 0.01 level of Significance; '*' Significant at 0.05 level of Significance

\section{Fresh root weight}

The fresh root weight of cauliflower was found to be significantly influenced by treatments application. The highest infested fresh root weight $\left(0.934 \mathrm{~kg} \mathrm{~m}^{-2}\right)$ was recorded in control treatment. Whereas, the least fresh root weight $\left(0.41 \mathrm{~kg} \mathrm{~m}^{-2}\right)$ was recorded in Trichoderma viride treatment which was at par with fresh root weight in Nebijin, Hatake, lime treatment which had $0.397 \mathrm{~kg} \mathrm{~m}^{-2}, 0.416 \mathrm{~kg} \mathrm{~m}^{-2}, 0.600 \mathrm{~kg} \mathrm{~m}^{-2}, 0.636$ $\mathrm{kgm}^{-2}$ respectively. This statistical analyze shows that control plots had highest root weight as compared to different treatment applied plots. Results are presented in Table 7.

Table 7. Influence of treatments on the fresh root weight $\left(\mathrm{kgm}^{-2}\right)$ of white top variety of cauliflower

\begin{tabular}{lc}
\hline Treatments & Fresh root weight $\left(\mathrm{kgm}^{-2}\right)$ \\
\hline Control & $0.934 \mathrm{a}$ \\
Lime & $0.636 \mathrm{~b}$ \\
Trichoderma viride & $0.397 \mathrm{~b}$ \\
Nebijin & $0.416 \mathrm{~b}$ \\
Hatake & $0.600 \mathrm{~b}$ \\
\hline SEM \pm & 0.0761 \\
LSD & $0.2345^{* *}$ \\
C.V $(\%)$ & 25.5 \\
Grand mean & 0.597 \\
\hline
\end{tabular}

Note: SEM \pm , Standard Error of mean; C.V, Coefficient of variation; LSD, Least significant difference. Means in the column with same letter (s) in superscript indicate no significant difference between treatments at 0.05 level of significance; '***' Significant at 0.001 level of Significance; ' $* *$ ' Significant at 0.01 level of Significance; '*' Significant at 0.05 level of Significance 
From the fresh root weight study it shows that control plots has higher root weight compared to other treatments applied which was supported by Hwang et al.,(2012) studied that severely affected roots showed higher weight due to increase in cell numbers and cell size. Primarily symptoms are seen in the root system the form of swellings and deformations known as clubs which are caused due to cellular hyperplasia (increase in cellular number) and cellular hypertrophy (increase in cellular size).

\section{CONCLUSION}

Nebijin is highly effective fungicide for the control of the club root disease of Cole crops. However, the bio-fungicides Hatake and Trichoderma had also effective control against the club root disease. The lowest disease incidence $(50.2 \%)$, severity index $(26.8 \%)$ and the highest percent disease control $(57.6 \%)$ was recorded in Nebijin treatment. Moreover, the Marketable yield $\left(\mathrm{Mtha}^{-1}\right)$ of cauliflower per plot was observed highest from Nebijin (48.27 $\mathrm{Mtha}^{-1}$ ) and Trichoderma viride (47.39 $\mathrm{Mtha}^{-1}$ ) treatment. The effect of treatments was non-significant for all the vegetative parameters. Nebijin could be an effective option for thenon- organic commercial growers for bulk production of Cole crop. Likewise, bio-fungicides should be promoted for the organic production and for the long-term quality of soil. Despite the effectiveness of Nebijin in controlling disease, main pitfall of the Nebijin is cost and un-affordability of the farmers in long-term basis. Nebijin is formulated for the soil incorporation which causes the quantity losses and directly increases the cost of production. So, Researches should be conducted on the different application methods of Nebijin that would minimize the quantity loss of Nebijin and further development works should be conducted to establish it as cost- effective method against the club root disease of cole crops.

\section{ACKNOWLEDGEMENT}

We would like to acknowledge our indebtedness and render our warmest thanks to Agriculture and forestry University, Rampur, Chitwan; Prime minister Agriculture Modernization project (PMAMP), Makwanpur and Pankaj Raj Dhital, Assistant Professor for guiding throughout the study period.

\section{REFERENCES}

APP. (1955). Nepal agriculture perspective plan, Final report. Agricultural Projects Service Centre.

Basnet, T.B., Adhikari, D.R., Ghimire, P. and Khatiwada, S. (2018). Management of clubroot disease of cauliflower in Kavre, Nepal. Nepalese Journal of Agricultural Sciences, 17:94-100.

Burnett, F. (2013). Management of Clubroot (Plasmodiophora Brassicae )in winter Oilseed Rape. HGCA,Project Report No.487. 
Colhoun, J. (1953). A study of the epidemiology of club-root disease of Brassicae. Annals of Applied Biology, 40:262-283.

Cuevas, V., Lagman, C.J. and Cuevas, A. (2011). Potential impact of the use of Trichoderma spp. on Farmer's profit in the field control of clubroot disease of crucifers caused by Plasmodiophora brassicae Wor. The Philippine Agricultural Scientist, 94(2): 171-178.

Dixon, G.R. (2009). The occurrence and economic impact of Plasmodiophora Brassicae and clubroot disease. Journal of Plant Growth Regulation, 28(3): 194-202.

Ghimire, A. and Shrestha, S. (2019). Effect of Cultural and Biological Treatments in Managing Clubroot Disease of Cabbage in Sidhuwa, Nepal. International Journal of Applied Sciences and Biotechnology, 7:96-101.

Hatake. (2018). Biofertilizer Biofungicide. https://hatake-global.com/our-products.Accessed on $26^{\text {th }}$ October, 2019.

Hwang, S.F., Strelkov, S.E., Feng, J., Gossen, B.D. and Howard, R.J. (2012). Plasmodiophora brassicae: A review of an emerging pathogen of the Canadian canola (Brassica napus) crop. Molecular Plant Pathology, 13(2): 105-113.

Joshi, T.N., Budha, C.B., Sharma, S., Baral, S.R., Pandey, N.L. and Rajbhandari, R. (2018). Effect of Different Plant spacing on the Production of Hybrid Cauliflower (Brassica Oleraceae Var.Botrytis) Under the Agro- Climatic Conditions of mid-hills Region of Nepal. Plant Sciences and Crop Protection, 1(1):105.

Karling, J.S. (1968). The Plasmodiophorales including a complete host index, bibliography, and a description of diseases caused by species of this order. New York Hafner PubLishing Company.

Kuginuki, Y., Yoshikawa, H. and Hirai, M. (1999). Variation in Virulence of Plasmodiophora Brassicae in Japan Tested with Clubroot-resistance Cultivars of Chinese Cabbage (Brassica rapa L. ssp. pekinensis). European Journal of Plant Pathology, 105(4):327332.

MOAD, (2016). Ministry of Agricultural Development (MOAD). Statistical Information of Nepalese Agriculture .Government of Nepal.

PPD. (2000). Annual Report. Latipur, Nepal:Plant Pathology Division, Nepal Agriculture Research Council.

Singh, R. kumar. (2010). Trichoderma: A bio-control agent for management soil born diseases. http://agropedia.iitk.ac.in/content/trichoderma-bio-control-agent-management -soil-born-diseases. Accessed on $27^{\text {th }}$ October, 2019.

Tanaka, S., Kochi, S.I., Kunita, H., Ito, S.I. and Kameya-Iwaki, M. (1999). Biological mode of action of the fungicide Flusulfamide against Plasmodiophora brassicae(clubroot). European Journal of Plant Pathology, 105: 577-584.

Timila, R.D. and Neupane, J. (2008). Nebijin (flusulfamide) on the Management of Clubroot Disease of Cauliflower. Proceedings of the Fifth National Seminar on Horticulture ,Nepal Agriculture Research Council (NARC), Khumaltar, Lalitpur, Nepal, 274-279.

Timila, R.D. (2006). Review on root management of clubroot disease:A challenge for vegetable (Brassicas) cultivation in Nepal. Proceedings of the Plant Protection Society Nepal, 90-99. 
Tremblay, N., Belec, C., Coulombe, J. and Godin, C. (2005). Evaluation of calcium cyanamide and liming for control of clubroot disease in cauliflower. Crop Protection, 24:798-803.

Webster, M.A. and Dixon, G.R. (1991). Calcium, pH and inoculum concentration influencing colonization by Plasodiophora brassicae. Mycological Research, 95(1): 64-73. 